This item was submitted to Loughborough's Research Repository by the author.

Items in Figshare are protected by copyright, with all rights reserved, unless otherwise indicated.

\title{
Similarly different: a comparison of HRM practices in MNE subsidiaries and local firms in Turkey
}

PLEASE CITE THE PUBLISHED VERSION

https://doi.org/10.1080/09585192.2013.781434

\section{PUBLISHER}

(c) Taylor and Francis

\section{VERSION}

AM (Accepted Manuscript)

\section{PUBLISHER STATEMENT}

This work is made available according to the conditions of the Creative Commons Attribution-NonCommercialNoDerivatives 4.0 International (CC BY-NC-ND 4.0) licence. Full details of this licence are available at: https://creativecommons.org/licenses/by-nc-nd/4.0/

\section{LICENCE}

CC BY-NC-ND 4.0

\section{REPOSITORY RECORD}

Mellahi, Kamel, Mehmet Demirbag, David G. Collings, Ekrem Tatoglu, and Mathew Hughes. 2019. "Similarly Different: A Comparison of HRM Practices in MNE Subsidiaries and Local Firms in Turkey". figshare. https://hdl.handle.net/2134/26358. 


\title{
Similarly Different: A Comparison of HRM Practices in MNE Subsidiaries and Local Firms in Turkey
}

\author{
by \\ Kamel Mellahi $^{\text {a\# }}$, Mehmet Demirbag ${ }^{\text {b }}$, David G. Collings ${ }^{c}$, Ekrem Tatoglu ${ }^{d}$, \\ Mathew Hughes ${ }^{\mathrm{e}}$
}

${ }^{\text {a }}$ Professor of Strategic Management, Warwick Business School, The University of Warwick, Coventry, CV4 7AL, United Kingdom.

${ }^{\mathbf{b}}$ Professor of International Business, Management School, The University of Sheffield, Sheffield, S1 4DT, United Kingdom.

${ }^{\mathbf{c}}$ Senior Lecturer in International Management, J.E. Cairnes School of Business and Economics, National University of Ireland, Galway, Ireland.

${ }^{\mathbf{d}}$ Professor of International Business, Chair of International Trade and Business, Faculty of Economics and Administrative Sciences, Bahcesehir University, Besiktas, Istanbul, 34349, Turkey.

${ }^{\mathbf{e}}$ Associate Professor in Entrepreneurship and Innovation, Nottingham University Business School, University of Nottingham, Jubilee Campus, Nottingham, NG8 1BB

${ }^{\#}$ Corresponding author:

Professor Kamel Mellahi, Warwick Business School, The University of Warwick, Coventry, CV4 7AL

United Kingdom

Email: kamel.mellahi@wbs.ac.uk 


\title{
Similarly Different: A Comparison of HRM Practices in MNE Subsidiaries and Local Firms in Turkey
}

\begin{abstract}
This study provides some important insights on identifying the underlying characteristics of HRM practices that are likely to be adapted to the local cultural and institutional milieu by subsidiaries of MNEs. Further insights are provided on the distinctive characteristics of HRM practices pursued by local firms that are more likely to converge to the practices pursued by subsidiaries of MNEs. Our findings support the idea that HRM practices that are easy to diffuse, control and manage and reflect a core organizational value will not be adapted to the local context. Our results provide evidence of the emergence of an established set of global best practices in MNEs. We also identify some instances where MNEs are more likely to adapt their HRM practices to the local context. We posit that this is more likely with regard to HRM practices that are difficult to diffuse, control and manage and require sensitivity to local institutional pressures.
\end{abstract}

Keywords: HRM, MNE subsidiaries, institutional theory, Turkey. 


\section{Introduction}

The issue of how and why subsidiaries of multinational enterprises (MNEs) alter their management practices in order to fit local contexts has been a vexing question which international human resource management (HRM) scholars have wrestled with for over three decades (Björkman and Lervik 2007). This paper contributes to this line of inquiry by comparing HRM practices of subsidiaries of MNEs to those of local firms operating in Turkey in an attempt to understand why certain HRM practices converge while other diverge. Specifically, we aim to identify the factors that explain the similarities and differences in the relative use of high-performance HRM practices (Huselid 1995) between subsidiaries of MNEs operating in Turkey and local Turkish firms.

Over the last three decades, a number of studies have compared HRM practices of subsidiaries of MNEs with those used by local firms. The results of these studies are not consistent and are often difficult to interpret (Tregaskis and Brewster 2006). While a number of studies comparing HRM practices of subsidiaries of MNEs with those of indigenous firms found both similarities and differences (see for example, Hamil's (1984) and Purcell et al.'s (1987) studies in the UK, Rodwell and Teo's (1999) and McGraw's (2002) in Australia, Hiltrop (1999) in Belgium, Huang (2000) in Taiwan), several studies did not reveal substantial differences (see for example Beaumont et al.'s (1990) study of German MNEs in the UK, Rosenzweig and Nohria's (1994) study of MNEs' affiliates in the USA; and Turner et al.'s (2001) studies in Ireland). In addition to the inconsistency of the results, the underlying reasons for such similarities and differences are not fully understood (Geary and Roche 2001). For instance, Gunnigle et al. (2002) posit that the strength of the institutional context of the host country determines the level of similarities and differences between subsidiaries of MNEs and local firms. But such statements do not specify which practices are likely to be influenced by the institutional context and which are not, nor do they explain why the convergence is not apparent in each instance and nor do they explain what features are exhibited by those HRM practices more likely to converge than diverge. Other broad explanations for the convergence or divergence of HRM practices between MNEs' affiliates 
and local firms lack specificity. Scholars using institutional theory, for example, suggest that organizations are increasingly being driven by a 'common logic of industrialism' or a common set of managerial requirements regardless of cultural difference which means that managerial practices are likely to become more homogenous globally. Other scholars (see for example Pudelko and Harzing 2007) argue that the HRM function is showing signs of converging on the US dominant model regardless of context. These arguments, while helpful, do not specify which—and why certain—HRM practices are converging and others are not.

The above discussion therefore suggests that much more research is needed to understand why HRM practices are more or less likely to be adapted to the local cultural and institutional milieu by subsidiaries of MNEs. Moreover, a consideration of the adaptation (or otherwise) of HRM practices pursued by local firms to converge with the practices of subsidiaries of MNEs is also necessary, otherwise the treatment of why convergence appears or does not appear to be happening in a county context is inadequate and incomplete.

We submit that the notion that different HRM practices are subject to different forces of convergence or divergence is not a new one (Rosenzweig and Nohria 1994; Sparrow et al. 1994; Ferner et al. 2001; Tregaskis and Brewster 2006; Almond 2011). However, in this paper we seek to go a step further and group HRM practices according to the forces that might determine the convergence (or divergence) of the HRM practices of subsidiaries of MNEs and local firms. The contribution of the work is centred on, first, understanding why certain HRM practices converge while others do not (research question 1). The second, and interrelated, contribution is centred on understanding why and which HRM practices are adapted to the new context by both the MNE and domestic firms (research question 2). With respect to the first contribution, we use an extension of institutional theory based on institutional dualism to argue that the tandem pressures of the external institutional environment and the internal firm institutional environment create competing pressures for the convergence and divergence of HRM practices. The former is driven in part by the need to establish legitimacy in the new context and to fit to the institutional framework of the country; but the latter is driven by pressure from headquarters to maintain established organisational practices that are important to the firm. For the second contribution, we demonstrate that these same pressures affect 
convergence by domestic firms towards international practice so far as for MNEs to converge with local practice. In effect, convergence is occurring at dual levels in that while MNEs maintain a divergence policy on practices pressured primarily by internal institutional drivers, local firms converge towards these international practices through external institutional pressures. In both instances however, the malleability of HRM practices is central in determining which practices are adapted and which are not because these characteristics change the priority attributed to internal versus external institutional pressures.

We argue that two key factors determine whether MNEs alter their HRM practices to local contexts: the relative ease of diffusing and managing a standard but internally-valued practice across borders (Björkman and Lervik 2007) and the strength of local cultural and institutional imperatives (Gunnigle et al. 2002). It is widely reported that MNEs use certain HR practices as critical mechanisms for coordinating and controlling the activities of their subsidiaries (Bartlett and Ghoshal 1989; Teagarden and Von Glinow 1997; Björkman and Lervik 2007), and therefore are less likely to alter such practices to fit the local context because of their importance to the organization. On the other hand, local cultural and institutional imperatives have different bearing on the decision to alter certain HRM practices over others (Björkman and Lervik 2007). For subsidiaries of MNEs entering new markets, the need to establish legitimacy and adapt to institutionally-accepted practice creates an external driver that might overrule internal pressures. For local firms operating in emerging economies such as Turkey (which forms the context of the current study), while they seek to emulate subsidiaries of MNEs in order to achieve higher business performance, they are not always able to do so (Cooke et al. 2011; Sahadev and Demirbag 2011). They may lack the necessary resources and capabilities to implement certain practices such as extensive training programs.

We believe the contributions of this work are important to the convergence-divergence debate. Over three decades of research into the convergence-divergence debate has failed to lead to a unified understanding of why HRM practices are adapted or not to a new country context. Björkman and Lervik (2007) argue that this is no small part due to the tendency for studies to ignore organizational pressures relative to external institutional pressures. Further, MNEs are considered in isolation and generally not compared to local firms in host 
economies. Unsurprisingly, these problems have led to broad explanations for the convergence or divergence of HRM practices between MNEs' affiliates and local firms to emerge-explanations that lack specificity. In assessing the external and internal institutional pressures in conjunction with the characteristics of HRM practices that render them more or less vulnerable to either form of pressure, we seek to provide important information to support a growing shift towards more complete treatments of the convergence-divergence problem-a problem relevant to scholars seeking to explain the adoption of HRM practices but also a problem relevant to managers in understanding how best to adapt to a different market context.

Before we move to theoretical framing and hypothesis development, it is important to explain our choice of country context. We chose Turkey-the largest economy in the SouthEastern European region-for this study for a number of reasons. Firstly, Turkey represents a particularly divergent site for the consideration of HRM practices owing to the divergent 'socio-cultural contingencies' (Budhwar and Mellahi 2007; Pudelko and Harzing 2007; Collings et al. 2010; Mellahi, Demirbag and Riddle 2011) evident there. Second, it is a developing economy and the GLOBE study identifies Turkey as below the world average in terms of performance and future orientation and above average on in-group collectivism, power distance and assertiveness (Kabasakal and Bodur 1998). Furthermore, Turkish firms are characterized by centralized decision making, reliance on short-term planning and highly personalized and strong leadership combined with limited delegation (Ronen 1986; FikretPasa et al. 2001; Glaister et al. 2008). On balance, these and other characteristics mean that organizations often experience difficulties in adopting new, Western HRM practices there (Tanova and Nadiri 2005). In addition, Turkey is an instructive case as it is currently at the centre of several debates due to its ongoing membership negotiations with the EU. The characteristics of the Turkish economy and its strategic location as a bridgehead between East and West, taken together with the aforementioned factors, make Turkey an interesting case to examine the nature of HRM practices and to undertake a comparative study of the convergence/divergence link between subsidiaries of MNEs and local Turkish firms. 


\section{Theoretical Framework and Hypotheses Development}

Although a plethora of HRM practices could be investigated by any one study, recent research has tended to focus on sets of HRM practices treated as a system (Wright and Boswell 2002; Boxall and Macky 2009). This has come to be known as a 'high performance work system' (HPWS) (Huselid 1995), or otherwise as a HRM configuration (Delery and Doty 1996). In general, this consists of competence-based performance appraisal, performance-based compensation, internal communication, employee empowerment, HRM department status, employee training and merit-based promotion. These HRM practices influence employees' abilities and employees' motivation and are considered important to the performance of successful firms (Huselid 1995; Minbaeva et al. 2003). As a consequence, these practices are most likely to be subject to forces driving their convergence (or divergence) when entering a new context. It is for this reason that we examine these HRM practices in particular.

The extent to which subsidiaries of MNEs diverge from local firms with respect to their HRM practices is a key issue for management scholars. A key theoretical approach which is synonymous with this debate is institutional theory (Björkman and Lervik 2007). The underlying thesis of this approach is that advances in technology and communications are creating a less differentiated world order, where differences in management practices perpetuated by geographic isolation of businesses are superseded by the logic of technology; hence management practices are expected to converge globally (Kidger 1991). Institutional theory suggests that organizations have a tendency to copy what is done elsewhere in an attempt to gain legitimacy or to gain the support of external agencies within a society (Strauss and Hanson 1997). In other words, organizations face pressures to be consistent with their external 'institutional' environment. DiMaggio and Powell (1983) considered three pressures that could cause an organization to alter its structure and conform to an institutional pattern, a process they term isomorphism: (1) coercive isomorphism, which originates from political influence and issues of legitimacy, whereby patterns are imposed on organizations by a more powerful authority; (2) mimetic isomorphism resulting from standardized responses to uncertainty whereby in an attempt to adapt to uncertainty, organizations respond by duplicating the patterns of other successful organizations; (3) normative isomorphism, linked 
to professionalism, where organizations adopt patterns considered appropriate for the environment ${ }^{1}$. Isomorphic tendencies are significant as they can explain the similarity among a set of organizations at a given point in time (Deephouse 1996). At an organizational level of analysis these isomorphic pressures influence a MNE's desire to standardize their HRM polices vis-à-vis the requirement to localize these policies or adapt them to local conditions (see Pudelko and Harzing 2007, p. 538). At a macro level these isomorphic pressures suggest convergence onto a dominant model of management.

Theoretically the literature is somewhat contradictory with regard to the implications of isomorphism for HRM practice. On the one hand, at the macro level, there is broad agreement that dominant modern conceptions of the field of HRM are strongly influenced by US thinking (Guest 1990, 2011; Brewster 2007; Thompson 2011). Thus, there is an expectation that US models will gain a hegemonic position in the global business context and that all HRM practices will ultimately converge on this US model. Authors such as Kidger (1991) and DiMaggio and Powell (1983) argue that US MNEs, business schools and consultants will contribute to global convergence on US conceptualizations of HRM, reflected in HRM practices across the world (see Brewster 2007, for a recent review). On the other hand, at a meso level, there is a relatively broad body of literature which identified HRM as one of the functions which is most likely to conform to local norms (see Rosenzweig 2006, for a review), suggesting continued divergence in HRM practice globally alongside convergence between MNE subsidiaries and local firms with regard to HRM practice in host economies.

Owing to the fact that HRM practice decisions are often mandated by local legislation and strongly influenced by custom and practice in the local labour market, a higher level of localization and hence convergence between MNE subsidiaries and local firms, makes intuitive sense. However, the debate is not as straightforward as such a simple interpretation would suggest. This is due to the fact that MNE subsidiaries occupy, in the language of institutional theory, dual institutional environments-that of the host country and that of the home country. This institutional duality (Rosenzweig and Nohria 1994; Kostova 1999;

\footnotetext{
1 See Rosenzweig and Nohria (1994, p. 230-231) for a discussion of how these influences may play out in MNEs.
} 
Kostova and Roth 2002) means that subsidiaries of MNEs can face competing legitimacy challenges. Practices that are judged as legitimate by the home country institutional environment may not be judged as legitimate by the host country environment, and vice versa, and managers of MNEs must balance these dual pressures. Indeed, a key argument of institutional theory is that environments shape organizational structures and practices not only through technological or material imperatives but also through cultural norms, symbols, beliefs and rituals (Suchman 1995). This means that while best practices are generally developed under the particular cultural and institutional context of the home country of a MNE, adoption is likely to be particularly difficult in countries which operate under divergent socio-cultural contingencies (Pudelko and Harzing 2007).

While institutional theory tends to capture the external environmental pressures on practices between MNEs and local firms to converge or diverge, internal environment pressures also complicate this issue by creating their own institutional effects driven by the culture and core values of the firm, which in part stem form the institutional context of the country of origin. Therefore, despite institutional pressure from the outside, there may also be institutional pressure from the inside of the MNE for its subsidiary to converge with the demands of the headquarters as opposed to the local environment. In turn, whether MNEs alter their HRM practices to local contexts depends on: (1) the relative ease of diffusing and managing a standard practice across borders and the extent to which that standard practice is important and considered a fundamental organizational value to the MNE (Björkman and Lervik 2007); and (2) the strength of local cultural and institutional imperatives to create a change in practice provided that the practice in question is not easy to manage from the headquarters (Gunnigle et al. 2002). These conditions alter the extent to which the perceived external institutional pressure to adapt to local conditions is truly high compared to the internal institutional pressure to maintain existing standard practice.

To put these theoretical mechanisms into perspective, it is widely reported that MNEs use certain HRM practices as critical mechanisms for coordinating and controlling the activities of their subsidiaries (Bartlett and Ghoshal 1989; Teagarden and Von Glinow 1997; Björkman and Lervik 2007), and therefore are less likely to alter such practices to fit the local 
context because the internal institutional pressure (from the headquarters) to conform is higher than the opposing external institutional pressure to adapt. On the other hand, local cultural and institutional imperatives create external institutional pressures to alter certain HRM practices to establish legitimacy in the host country (Gunnigle et al. 2002; Björkman and Lervik 2007). In this respect, MNEs are buffeted by coercive and normative pressures to adapt HRM practices to gain legitimacy from an external perspective but face similar forces internally in relation to high-valued, core HRM practices to maintain organizational practices over and above adapting to established practices in the host country.

It is not only MNEs that face these dual pressures though. Local domestic firms face mimetic isomorphic pressures to duplicate patterns seen as successful in other firms. When MNEs enter a new host country, the uncertainty created at the local level as a result of this new entry tends to promote mimetic behaviour as a response to this uncertainty. In effect then, local firms face external institutional pressures to either adhere to the established practices of the country or to undertake their own convergence towards the successful patterns exhibited by new entrants. Thus, in theory, the same sets of pressures are driving the convergencedivergence dilemma across both the subsidiaries of MNEs and local firms.

Based on these mechanisms, we group HRM practices into two categories in an attempt to understand which ones are more malleable to external pressure to change versus internal pressures to adhere: (1) practices easy to diffuse, control and manage from the centre whereby the ability to enact the practice prescribed by the headquarters at the subsidiary level is deemed important and necessary to the values of the MNE and can be done so in a straightforward manner. Practices here include: competence-based performance appraisal, performance-based compensation, internal communications, employee empowerment and the strategic emphasis placed on the HRM department. We expect these practices will not be altered by the MNE because they are core to its historical functioning and are easily diffused and controlled from the centre through its information systems. In effect then, the internal institutional pressure to maintain these HRM practices is expected to be higher than the external institutional pressure to adapt. However, significant differences with local Turkish firms are expected despite the possible presence of mimetic pressure to duplicate apparently 
successful patterns. Local Turkish firms are likely to remain under greater external institutional pressure to maintain legacy behaviours because HRM activities can be difficult to disentangle and interpret (e.g., Björkman and Lervik 2007); (2) practices influenced by cultural and institutional imperatives that render them hard to control and manage from the centre such that the external pressures to adapt are high. Practices here include: employee training and merit-based promotion. These practices are more dependent on local knowledge and expertise to manage the ongoing and on-ground activities of the subsidiary and so are more likely to adapt. Also, these are transparent practices that indicate best practice to local firms that enable them to compete at the local level. Thus, no significant differences with local Turkish firms would be expected. In effect then, convergence can occur in both sets of firms towards certain types of HRM practices owing to external pressures to adapt in the case of subsidiaries of MNEs, and external and internal institutional pressures to respond to the uncertainty of a new competitive threat with mimetic duplication of successful patters in the case of local firms.

Before elaborating on the development of our hypotheses it is instructive to comment briefly on the nature of HRM in the Turkish context. The dominant view of HRM in Turkey is summarized by Kaya (2006) thus: HRM remains an emerging approach in Turkish firms and hence application remains limited. Further, employees are rarely viewed as contributing significantly to organizational success-a view which stands in contrast to the mainstream Western view. Indeed, Tanova and Nadiri (2005) report the difficulties experienced by organizations in attempting to introduce HRM practices due to the nature of societal and organizational cultures in Turkey. Local management's frame of reference in this regard is significant, as not only will it influence HRM practices in local firms, but one would also expect that it may influence the implementation of HRM practices in local subsidiaries of MNEs.

These challenges are generally traced to the cultural context in Turkey. Turkey is generally classified as below the world average on performance and future orientation and above average on in-group collectivism, power distance and assertiveness (Kabasakal and Bodur 1998; Ozcelik and Ferman 2006). It is considered to be highly paternalistic, reflecting 
the perceived obligation among those in authority positions to provide support and protection to those under their care. Employees reciprocate such care through loyalty and deference to authority figures (Aycan and Kanungo 1998). We elaborate on specific aspects of the Turkish context of HRM in the development of the hypotheses below. Given these cultural characteristics, which are significantly at odds with many of the beliefs which underscore modern conceptions of HRM (see Guest 1990; Pfeffer 1998; Brewster 2007), which we expand upon below, we expect a degree of difference between practices in MNE subsidiaries and local firms in Turkey.

\subsection{HRM Practices Rigid to Organizational Values and Headquarter (HQ) Control}

Effective performance appraisal systems can facilitate the identification of individual performance levels and individual skills gaps which require development. Scott-Lennon (1995) argues that performance management has evolved from a mainly operational focus to a more strategically-oriented concept reflecting the key role that performance management and appraisal play in the HRM system. In turn, it is not surprising that competence-based performance appraisal plays a key role in MNEs (Chang et al. 2009). Chang et al. (2009) reported that in MNEs, performance is monitored and appraised on a continuous and constant basis with electronic data systems and scorecards in particular driving the process. MNEs and their subsidiaries are increasingly held accountable by internal and external stakeholders for their performance so direct headquarter control is paramount. In this respect, the perceived effect of any external institutional pressure on the subsidiary to adapt is likely to be much less than the perceived internal institutional pressure to retain a key organizational practice. However, the picture in Turkish firms is likely to be different as performance evaluation has been identified as one of the most challenging aspects of HRM in the Turkish context (Aycan 2001). Aycan (2001) identifies a lack of objectivity in performance appraisals, which itself results from a lack of scientific validity for the measures used to evaluate performance and a lack of training for appraisers. Culturally, the high-power distance orientation means that performance appraisal tended to be one way only with little opportunity for peer appraisal. Finally, Aycan (2001) points to the challenge of providing feedback in the Turkish context 
where individual employees get emotional when receiving negative feedback. This finding is reinforced by Ozcelik and Ferman's (2006) finding that managers were reluctant to give negative feedback to employees. Thus, significant differences would be expected between MNE subsidiaries and local firms because while MNE subsidiaries face internal institutional pressure to retain this existing practice, local Turkish firms face external institutional pressures that prevent mimetic duplication of such a practice. In turn, divergence would be expected in the case of performance evaluation.

A similar outcome is expected with respect to reward systems. Rewards are directly linked to performance appraisal systems (e.g., Huselid 1995). Given that individual performance is typically an organizational value in MNEs; the likelihood that a competencebased performance appraisal system is accompanied by aggressive performance-based compensation is high. Indeed, high reward, contingent on performance, was identified as a key high-performance practice by Pfeffer (1998), and Delery and Doty (1996) identify performance-based compensation as the single strongest predictor of firm performance in their study. Further, the use of pay for performance systems has been associated with the ability to attract higher than average workers to organizations (Lazear 2000). However, there is a body of literature which identifies the use and management of incentives in a symbolic sense, indicative of a desire to signal that the company belongs to a particular social context (St-Onge et al. 2001). Thus "the management of incentives not only is used to align the interests of principal and agent, but also has a symbolic character, insofar as it signals that the company belongs to a particular social context" (Fernandez-Alles et al. 2006, p. 961). Hence we would expect to see far more developed performance-based compensation systems in MNE subsidiaries operating in Turkey based also on economic rationality and mimetic isomorphism.

The logic of this argumentation could be expected to follow through to indigenous Turkish firms; however, the situation is not so clear cut. Firstly, Turkey scores below average on performance and future orientation (Kabasakal and Bodur 1998), which may not align well with performance-based compensation systems. Secondly, although the characteristic has declined in recent years, Turkey scores quite highly on collectivism in Hofstede's (1980) 
study. Together, these characteristics suggest that local firms may not align well with individualist performance based compensation systems. In turn, these external institutional pressures on local firms would likely prevent convergence towards a MNE practice while internal pressures from the interactions among dimensions of HPWS and organizational culture would be expected to create internal institutional pressure for divergence.

For competence-based appraisal and performance-based compensation systems to work well, a high degree of internal information sharing and internal communications would be expected (e.g., Huselid 1995). A reliance on fluid internal communications can be thought of as a core value of MNEs and many reflect this in their strategy charters. Information sharing has been identified as a key HRM practice (Pfeffer 1998), for example, and it is associated with a higher level of trust between workers and management, is argued to facilitate team working through providing employees with information on which they can base their suggestions for improvements in business processes, and is necessary to fuel the development of innovation, learning and competitive advantage particularly when firms exhibit complex MNE structures (e.g., Minbaeva et al. 2003; Kang and Snell 2009). Greater internal employee communications increases the degree of connectedness among employees to enable superior performance (Jansen et al. 2006). Therefore, we expect to see high levels of internal communication in MNEs.

The situation in domestic Turkish firms is less clear. While authors such as Aycan and Fikret-Pasa (2000) call for organizations to provide more opportunities for communication with their employees in the Turkish context, the country is still classified as highly paternalistic, moderately hierarchical and collectivist. Hence it is logical to expect that in relative terms at least, Turkish firms will not display as high levels of internal communication as their MNE counterparts and the external institutional forces shaped by these features of national culture are unlikely to encourage any mimetic convergence either. A further issue likely to compound this difference is that there is a much weaker local imperative to implement fluid internal communication channels because employees expect to be led by senior managers. Research studies reporting that the highly paternalistic tendencies in Turkish firms reflect a perceived obligation among those in authority positions to provide support and 
protection to those under their care with employees reciprocating such care through loyalty and deference to authority figures support this view (Aycan and Kanungo 1998). Thus, we expect MNE subsidiaries and Turkish firms to differ greatly on this HRM practice owing to the conflicting pressures both sets of firms face.

In a similar vein to internal employee communication, employee empowerment or involving employees in decision making in organizations and team working have been demonstrated to impact favourably on organizational performance (McDuffie 1995; Park et al 2010). It is seen to represent a non-hierarchical mode of operation and may increase employee commitment to the organization (Fey et al. 2000). We would expect empowerment to be evident in MNE subsidiaries as it is a corollary organizational value that supports the aims of generating greater internal communications, as supported by research into corporate entrepreneurship, for example (Hayton 2005). Conversely, many of the cultural traditions of Turkey make empowerment somewhat less likely and far less prevalent in Turkish firms. In much the same way that a lack of local imperative exists for internal communications, the highly paternalistic and moderately hierarchical cultural traits associated with Turkey are likely to be particularly relevant in reducing the prevalence of empowerment there (Aycan et al. 2000). This is despite Aycan and Fikret-Pasa's (2000) call for organizations to provide more opportunities for empowerment to their employees. The lack of external institutional pressure to initiate employee empowerment is apparent when considering such cultural forces. But in MNEs there is internal institutional pressure from the centre owing to the performance prerogative of MNEs and the stakeholder pressure to achieve. Combined with competencebased appraisals and performance-based compensation, employee empowerment is necessary to the performance of complex and large organizations (e.g., Hayton 2005; Kang and Snell 2009). Thus, significant differences are expected between MNE subsidiaries and domestic Turkish firms on this HRM practice.

A key theme in much of the recent literature on HRM has been the search for the strategic role of the HRM function. Given that human resources are increasingly viewed as a key source of competitive advantage (Barney 1991; Collings and Mellahi, 2009), it is sensible that progressive organizations afford a higher status to the HRM department. The empirical 
evidence which posits a positive relationship between the deployment of high-performance HRM practices and firm performance reinforces this trend (Huselid et al. 1997; Guthrie 2001). Indeed, in a number of countries MNEs were specifically identified as introducing innovations with regard to a more strategic role for the HRM function (see Gunnigle 1998, in the Irish context, for example). Hence, we expect MNE subsidiaries to emphasize the strategic role of the HRM function owing to the external institutional pressures among high-performing MNEs to persistently draw the best out of their employees and the subsequent internal pressure to retain high-performing members of staff. Divergence from this standpoint is then highly unlikely regardless of any institutional pressure from entering a new host country.

In contrast, the HRM function in Turkish firms is very much playing catch up with counterparts in more developed countries. Less than a decade ago, Aycan (2001, p. 252) described it as a 'developing field' in a 'developing country'. Aycan (2001) also alludes to a lack of available know-how within the Turkish HRM community to innovate with regard to HRM practice. A contributing institutional factor may be the volatile political and economic climate in Turkey which means that organizations may find it difficult to formulate long term plans (Aycan 2001; Glaister et al. 2008). While recent evidence has suggested a more positive outlook for the HRM function there (Ozcelik and Aydinli 2006), on balance we expect that the status of the HRM department will be less developed in Turkish firms than in their MNE counterparts with institutional barriers preventing any rapid convergence.

Drawing these arguments together leads to the following multi-part hypothesis:

H1: HRM practices that are easy to diffuse, control and manage and reflect a core organizational value will not be adapted to the local context. Specifically, significant differences are expected between MNE subsidiaries located in Turkey and domestic Turkish firms in relation to (a) competence-based performance appraisal, (b) performance-based compensation, (c) internal communications, (d) employee empowerment and (e) the strategic emphasis placed on the HRM department.

\subsection{HRM Practices Malleable to Institutional Context}

Employee training is widely regarded as a high-performance HRM practice (Huselid 1995; McDuffie 1995; Kuvass and Dysvik 2010). Owing to the fact that investment in employee 
training and development is associated with developing the human capital at the centre of the high performance HRM paradigm (Pfeffer 1998), one would expect that investment in training among MNEs would be relatively high (Tregaskis et al. 2001). However, the fundamental question is not whether the MNE invests in employee training or not but rather what form does this training take and, in turn, is this form contextualized to the MNE headquarters (owing to internal institutional pressure) or the host country (owing to external institutional pressure)? The need to learn more about the host country, its markets and its institutional framework, coupled with a need to shape competitive advantages against incumbent domestic firms, suggest that training should be adapted to the local environment context because the external and internal institutional pressures to do so are great. In a form of isomorphism, the MNE subsidiary will need to shape training programs that bear close similarity to local high-performing firms in order to embed the knowledge and skills needed to operate effectively in the host country. Based on our assumption about the highperformance bias of MNEs, it would seem likely that MNEs would adapt their training to the host country context to ensure its subsidiary can perform effectively in its new institutional environment. Thus we expect MNEs to display relatively high levels of investment in employee training adapted to the domestic context.

With respect to Turkish firms, Aycan (2001) has argued that training and development is one of the most important aspects of the HRM role for these firms. This may be linked to the nature of the Turkish educational system. Although standards have improved over recent years, the educational profile in Turkey has historically been relatively low. Employees enter the labour force with relatively low educational qualifications; although Aycan (2001) does point to an emerging cohort of young educated employees entering the workforce in the recent years preceding the study. Hosking and Anderson (1992) point to the key role the education system, as a key labour market institutional actor, has in influencing organizationallevel training and development activity. The competitive environment that Turkish firms now find themselves in also encourages investment in training. As institutional pressures change to accommodate emerging national and international competition, local firms face greater pressures to up-skill their employees. Put simply, there are competitive and institutional 
pressures for local firms to professionalize their training practices. Thus, we do not expect significant differences between MNE subsidiaries and domestic Turkish firms on this HRM practice because, although different in nature, the external institutional pressure on both sets of firms to converge around training investments tailored to the country context is high.

In one of the earliest contributions to the best practice HRM literature, Pfeffer (1998) called for employment security as an employee's perception of a long-term future within the firm was associated with higher levels of motivation. Guest (1997) argues that there is a link between the availability of internal career opportunities and organizational commitment of employees, owing to the perception that career opportunities are available. Merit-based promotion is an indication of the emphasis on internal labour markets and internal career development within organizations. Emphasizing internal promotion within the firm is likely to engender a sense of justice and fairness among employees (Fey et al. 2000). Hence, we expect MNEs to place a strong emphasis on merit-based promotion. But, we do not expect the MNE headquarter to control this promotion process as the pressure point exists in the subsidiary itself and its need to perform in the new institutional environment it now operates in. While appraisals and rewards are organization-wide, promotions are much more specific to the needs and circumstances of the individual subsidiary. Also, while a reward applies to many, promotion applies to a limited few in which the character of the person is as important as their performance (Mellahi and Collings 2010). Local managers are in a better position to make promotion judgements owing to the fact that supervision takes place at the local level (if we assume MNEs do promote employee empowerment as we suspect then this condition is yet more likely). Moreover, given that the cultural expectations and institutional tendencies of Turkey are towards paternalism and collectivism, with reciprocal obligations among top managers and employees to provide support for each other's interests through loyalty and deference (Aycan and Kanungo 1998; Kabasakal and Bodur 1998; Ozcelik and Ferman 2006), it would be expected that those who are meritorious on these softer issues beyond performance alone will face greater promotional prospects. To attract high-calibre employees, a MNE subsidiary would need to be attentive to these important institutional expectations. In recent years, the young and educated employees entering the Turkish workforce have 
aspiration and preferences more aligned with their Western counterparts (Aycan and FikretPasa 2000). Indeed, Aycan and Fikret-Pasa (2000) call for organizations to provide more developmental opportunities for their employees. Thus, we do not expect any significant difference between MNE subsidiaries and domestic Turkish firms on this HRM practice as both face converging pressures to meet the aspirations of the workforce.

Drawing these arguments together leads to the following multi-part hypothesis stated in the null form:

H2: HRM practices that are difficult to diffuse, control and manage and require sensitivity to local institutional pressures will be adapted to the local context. Specifically, no significant differences are expected between MNE subsidiaries located in Turkey and domestic Turkish firms in relation to (a) employee training and (b) merit-based promotion.

\subsection{HRM Practices and Subsidiary Characteristics}

Notwithstanding the above hypotheses, variations may exist among MNE subsidiaries themselves. While an institutional lens predicts convergence among MNEs, we expect to see variation between MNE subsidiaries that accommodate institutional pressures differently. For example, a large body of evidence points to the impact a MNE's country of origin has on management practice in its subsidiary operations. In this regard, Gunnigle et al. (2002) found a clear variation between HRM practices in firms of different national origin (see also Gooderham et al. 1998). Geppert and his colleagues also pointed to differences in the change management strategies pursued by organizations of different nationalities (Geppert et al. 2003). Specifically, American MNEs are characterized by formalized and centralized approaches to HRM while Japanese firms rely to a far greater degree on personal and less formal control mechanisms (see Almond 2011). Joint ventures (JV) by definition involve parent organizations from two or more different countries. Clearly these parents may have varying views around appropriate HRM practices for the organization (Shenkar and Zeira 1987). Indeed, each parent could force the JV to adopt specific HRM practices in line with their preferences and interpretation of institutional pressures (Geringer and Frayne 1990; Lu and Bjorkman 1997). The extent to which the JV is reliant on the host economy for critical 
resources is also likely to influence HRM practices (Lu and Bjorkman 1997). Hence, we expect variation in HRM practices in JVs compared to other firms. The literature further suggests that subsidiaries located on greenfield sites are subject to far less constraints than those established on brownfield sites or established through acquisitions in terms of introducing innovative management practices such as HRM (see Emery 1980; Whittaker 1986; Gunnigle 1995). Hence it is logical to expect differences in HRM practices between subsidiaries located on greenfield sites versus those established via an acquisition. In terms of institutional theory then, different effects from the country of origin, the vulnerability of the subsidiary's organizational mode to external pressure and the nature of the subsidiary itself will vary the extent to which the subsidiary is subject to external and internal institutional pressures, thereby altering the extent to which it needs to adapt its HRM practices. Thus:

H3: The level of emphasis on HRM practices by MNE subsidiaries located in Turkey varies with (a) the country of origin of MNEs, (b) the organizational mode of the subsidiary (i.e. WOS or JV) and (c) establishment mode of the subsidiary (i.e. greenfield or acquisition).

The conceptual framework and hypothesized relationships are summarized in Figure 1.

\section{[Insert Figure 1 over here]}

\section{Research Methods}

\subsection{Sample}

The sampling frame for the Turkish firms was drawn from the website of TOBB (The Union of Chambers of Commerce, Industry, Maritime Trade and Commodity Exchanges of Turkey, available at http://www.tobb.org.tr), which provides an industrial database that contains approximately 40,000 firms that are registered to any of 10 Chambers of Industry, 19 Chambers of Trade and 64 Chambers of Industry and Trade in Turkey. Within this sample frame, very small companies of fewer than 20 employees were excluded. This was not viewed as a serious threat to the study as such companies are likely to be managed entrepreneurially 
and so have no recognizable HRM system. Through a random sampling selection procedure, a total of 1000 firms was generated and constituted the sampling frame for the study.

A carefully constructed questionnaire, which was originally designed in English, was translated from English to Turkish and then retranslated into English by a second party to ensure accuracy in translation. This process of "back translation" is useful in identifying misinterpretations and misunderstandings before the questionnaire is administered. To further ensure the integrity of the translation, two bilingual translators were used in tandem to compare the back translated English and Turkish versions of the questionnaire and make necessary changes. The survey questionnaire was then mailed to the CEO of each company with a letter requesting that the CEO, or his/her senior executive in charge of HRM within the organization, should complete it. To ensure good quality responses, this letter also identified the researchers, explained the research purpose and assured confidentiality. After one reminder a total of 359 questionnaires were returned, of which 340 were usable (the remaining 19 were excluded owing to missing data), representing an effective response rate of $34.0 \%$, which was satisfactory, given the confidentiality and complexity of the questionnaire.

The sampling frame for MNE subsidiaries was drawn from the database of a government agency, the General Directorate of Foreign Investment (GDFI). From the original list of 19,909 FDI firms in the database as of May 2008 (GDFI 2008), a new dataset was compiled based on the capital value of the subsidiary and the proportion of foreign equity shareholding. Those ventures with capital value of less than one million USD were excluded. Most of these firms are owned by a single person or established by means of ordinary partnerships. For the purposes of this survey, it was not considered feasible to include these firms in the sampling frame. This study also uses the 10 per cent and 90 per cent cut-off points to capture the alternative ownership structures. The investments with foreign ownership of less than 10 per cent are considered to be portfolio investments and were excluded from the database. A venture is defined as a JV when foreign equity ownership ranges from 10 per cent to 90 per cent, while a venture with foreign equity shareholding of over 90 per cent is considered to be a WOS. This range is consistent with the definition of a 
JV used by the U.S. Department of Commerce. Park and Ungson (1997) and Demirbag et al. (2007) also followed the same definitions, for example.

Based on a random sampling selection procedure, a total of 500 firms was generated and constituted the sampling frame for the study. A questionnaire and a covering letter were posted to the CEO of each member company with a letter requesting that the CEO, or his/her senior executive in charge of HRM within the organization, should complete it. After one reminder, a total of 148 usable questionnaires were returned, representing a response rate of 29.6\%. Of this sample, 88 (59.5\%) were WOSs and 60 (40.5\%) were JVs. Regarding the establishment mode of subsidiary adopted by the MNE in the formation stage of subsidiary, 115 (77.7\%) were established by setting up new ventures (greenfield investments) and the remaining 33 (22.3\%) were formed by full or partial acquisition of existing local firms. The distribution of the sample in terms of the country of origin of the MNE subsidiaries are as follows: USA (29.6\% of the total), Germany (22.3\%), UK (13.5\%), France (4.1\%), Italy (4.1\%), Netherlands (4.1\%), Switzerland (4.1\%), other EU countries (6.7\%) and Asian countries $(11.5 \%)$.

For both samples of Turkish firms and MNE subsidiaries, ANOVA tests were used to examine the differences among means for the respondent categories. No significant differences $(p>0.1)$ were detected. Given the level of responsibility of respondents, the findings provide a good reflection of senior management's views on the nature of HRM practices. For each sample, the responding firms were also compared across the main characteristics of the sample such as industry type and geographical location, and again showed no systematic differences $(p>0.1)$.

The characteristics of Turkish firms and MNE subsidiaries are summarized in Table 1.

\section{[Insert Table 1 over here]}

\subsection{Measurement of Variables}

All of the measures used to capture data for the empirical analyses were sourced from previously administered questionnaires used earlier by Fey and Björkman (2001), Minbaeva et al. (2003) and Björkman et al. (2007). 
The dependent variable was categorical and measured by a dummy variable. A value of one was assigned for MNE subsidiaries operating in Turkey, while a zero value was assigned for domestic firms in Turkey.

The independent variables were measured as follows:

Competence-based performance appraisal (PERF_APP) was measured by an index composed of three items. The first item measures the proportion of the employees that regularly receive a formal evaluation of their performance (in per cent), the second item measures the proportion of jobs where a formal job analysis has been conducted (in per cent), and the final item measures the proportion of new jobs for which a formal analysis of the desired personal skills/competencies/characteristics is carried out prior to making a selection decision (in per cent) $(\alpha=0.80)$.

Performance-based compensation (PERF_COMP) was measured by four items. Relying on a five-point Likert scale (ranging from $1=$ not at all to $5=$ to a large extent) the first two items ask the respondents whether the firm uses performance-based compensation and to what extent their compensation systems are closely connected with the financial results of the firm. The third item captures whether pay is tied to individual performance, and the final item measures the extent to which differences in pay across employees in the firm represent differences in their contribution to the firm $(\alpha=0.67)$.

Internal communication (INT_COMM) is be defined as the extent to which exchange of information occurs within the firm and was measured by a scale composed of three items using five-point scales $(1=$ not at all to $5=$ to a large extent). The items denote communication flows between (i) employees in different departments, (ii) non-managerial employees and managerial employees, and (iii) the HRM department and the top management team $(\alpha=0.74)$.

Employee empowerment (EMPOWER) was measured by an index composed of three five-point scale items $(1=$ not at all to $5=$ to a large extent $)$. The first two items measure the extent to which employee input and suggestions are highly encouraged, and are often implemented, while the third item measures whether employees' capabilities are viewed as the firm's main source of competitive advantage $(\alpha=0.68)$. 
HRM department status (HRMD_STATUS) was measured through an index consisting of three five-point scales ( $1=$ not at all to $5=$ to a large extent). Respondents were asked the following questions: (i) to what extent do their firms make an explicit effort to align business and HRM/personnel strategies? (ii) to what extent is the HRM/personnel department involved in the strategic planning process? (iii) to what extent are HRM/personnel managers viewed by those outside the function as partners in the management of the business and agents for change? $(\alpha=0.80)$.

Employee training (TRAINING) was measured by two items including the number of days of formal training managerial and non-managerial employees receive annually $(\alpha=$ $0.79)$.

Merit-based promotion (MERIT_PRO) was measured by an index composed of three items. The first two items ask the respondents to what extent upper-level vacancies are filled from within, and whether qualified employees have the opportunity to be promoted to positions of greater pay and/or responsibility within the firm $(1=$ not at all to $5=$ to a large extent), while the third item measures whether the firm places a great deal of importance on merit when making promotion decisions $(\alpha=0.63)$.

MNE subsidiary characteristics were identified as follows:

In terms of the country of origin of MNE subsidiaries, the overall sample of MNE subsidiaries was partitioned into three groups. The first group consists of subsidiaries established by MNEs from the USA and the UK; the second group includes subsidiaries established by continental European MNEs; and the third group includes subsidiaries formed by Asian MNEs. The sample was partitioned, therefore, according to the geographical proximity of the MNEs to the Turkish market and the relatively similar business orientations of the firms in each group of countries stemming mainly from political, institutional and cultural factors. In this sense the UK-based MNEs are considered as adhering more to AngloAmerican business practices than are other Western European MNEs despite the fact that the UK is an important member of EU with its economy being closely tied to the EU. While the notion of HRM was originated in the US and has been widely acknowledged across the world, the underlying characteristics of both European and Asian countries are different from the 
USA and the UK. Differences in national and organizational cultures, a greater role of the State and different patterns of corporate governance have all led to variations in HRM practices across these three groups of countries (Brewster 2007). US HRM practices have typically been contrasted with European and Asian (particularly Japanese) HRM practices in the extant literature (Ferner 1997).

Regarding the organizational mode of MNE subsidiaries, the overall sample of MNE subsidiaries were categorized into two groups. The first group includes WOSs, while the second group consists of JVs. Similarly, in terms of the establishment mode of subsidiary adopted by the MNE in the formation stage of subsidiary, the overall sample of subsidiaries was partitioned into two groups: greenfield ventures versus acquisitions.

In line with earlier research (Fey and Björkman 2001; Minbaeva et al. 2003; Björkman et al. 2007), a set of three variables were included in the research framework to control for possible extraneous variation. Firm age (AGE) was incorporated as a control variable, since firms with more business experience have gone through a learning process concerning how to conduct business in the Turkish context. Firm size (LN_SIZE) was also controlled for as large firms may allocate more resources to the business and may tend to have more developed HRM systems and processes. Firm size was measured as the logarithm of the total number of employees in the firm. Since HRM practices may vary across industries, industry dummies were created for nine industry categories to control for the possible effect of industry characteristics: (1) industrial, automotive and electrical equipment (IND_ELECT); (2) food, textile and electrical equipment (FOOD_TEXT); (3) metal, wood, leather and glass (METAL_WOOD); (4) chemical and pharmaceuticals (CHEM_PHAR); (5) other manufacturing (OTH_MANUF); (6) wholesale and retail trade (TRADE); (7) computer and engineering services (COMP_ENG); (8) financial services and consultancy (FIN_CONS); and (9) hospitality and leisure services (HOSP_LEIS).

\subsection{Statistical Analysis}

The hypothesized relationships were tested by conducting two sets of analyses. The multi-part Hypotheses 1 (H1a to H1e) and 2 (H2a and H2b) were tested by conducting binomial logistic 
regressions, while Hypothesis 3 (H3a to H3c) was tested by means of two-tailed t-tests and ANOVA.

Due to the categorical nature of the dependent variable, a binary logistic regression procedure was used in testing $\mathrm{H} 1 \mathrm{a}, \mathrm{H} 1 \mathrm{~b}, \mathrm{H} 1 \mathrm{c}, \mathrm{H} 1 \mathrm{~d}, \mathrm{H} 1 \mathrm{e}, \mathrm{H} 2 \mathrm{a}$ and $\mathrm{H} 2 \mathrm{~b}$, which estimates the probability of an event occurring. The binary logistic model can be expressed as:

$$
P(Y \mathrm{i}=1)=1 /[1+\exp (-a-X i B)]
$$

where $Y \mathrm{i}$ is the dependent variable, defined by a dummy variable either 1 or 0 . The value of 1 denotes the probability of an event occurring rather than another as shown by the value of 0 . $X \mathrm{i}$ is the vector of independent variables for $i$ th observation, $a$ is the intercept parameter, $B$ is the vector of the regression parameters (Amemiya 1981). The regression coefficients estimate the impact of the independent variables on the probability of an event that occurs. A positive sign for the coefficient means that the variable increases the probability of the event occurring, a negative sign signifies the opposite. The maximum likelihood estimates of the parameters were obtained employing logistic regression. The explanatory power of the model is assessed using the model chi-square statistics, which test the null hypotheses that all parameter coefficients are zero, except the intercept term. The predictive ability of the model can be determined by the correct ratio, which shows the percentage reduction in classification errors with respect to random selection. However, to identify an acceptable level of predictive accuracy, the obtained correct ratio has to be compared to the rate that would have been obtained by chance. In the case of unequal group sizes the standard to calculate this rate should be proportional chance criterion. The formula for this criterion is: $\alpha^{2}+(1-\alpha)^{2}$ where $\alpha$ is the proportion of cases in group 1 and $1-\alpha$ is the proportion of cases in group 2. For a rough estimate of the acceptable level of predictive accuracy, Hair et al. (1995) suggest that the correct ratio should be at least one-fourth greater than the proportional chance criterion.

The final multi-part hypothesis (H3a to H3c), investigating to what extent the implementation of HRM practices by MNE subsidiaries located in Turkey varies with the characteristics of the sample, was tested by undertaking two-tailed t-tests and ANOVA as 
appropriate. The non-parametric equivalents of the above tests (Mann-Whitney $U$ and the Kruskal-Wallis Test) were also conducted to remove any doubts that may stem from the nature of the data. The non-parametric tests (not reported here) confirm the findings of the parametric tests.

\section{Results}

Prior to running the binomial logistic regression, a correlation matrix of the variables was prepared. The pairwise correlations were not large enough to warrant concern about possible multicollinearity problems. Table 2 presents descriptive statistics and correlation coefficients of independent variables in the study.

\section{[Insert Table 2 over here]}

A series of binomial logistic regressions were conducted to test the first two multi-part hypotheses (H1a to H1e; H2a and H2b). Table 3 shows the results of the logistic regression where the Turkish firms were taken as the base and given a zero value. The binomial logistic model explains to what extent the emphasis on the implementation of HRM practices varies between Turkish firms and MNE subsidiaries. A positive sign on the independent variable coefficients indicates the likelihood of the higher level of emphasis placed on the use of HRM practices by MNE subsidiaries in Turkey, while negative sign indicates that of the higher level of emphasis by domestic firms.

A total of nine logistic regression models were estimated, as shown in Table 3 . In the first step, the control variables were entered (Model 1). Of these variables, the firm age (AGE) had negative and significant coefficients, while the firm size (LN_SIZE) had positive and significant coefficients in all nine models in Table $3(\mathrm{p}<0.01)$. The industrial dummies had only modest effects. The individual effects of the hypothesized variables were then tested in Models 2 to 8, and the full model including all independent variables along with the control variables was tested in Model 9. All nine models have high overall explanatory power with significant chi-square values $(p<0.01)$. All the models have a good fit with correct ratios 
ranging from $78 \%$ to $72 \%$ of the observations, rates that are higher than would be expected by chance. The specificity (i.e. capacity to correctly predict Turkish firms) of the nine models ranges from $91 \%$ to $87 \%$, while their sensitivity (i.e. capacity to correctly predict MNE subsidiaries) ranges from 55\% to 36\%. Pseudo R-square measures confirm that the models have adequate explanatory power.

\section{[Insert Table 3 over here]}

As hypothesized by $\mathrm{H} 1 \mathrm{a}$, the coefficient of competence-based performance appraisal (PERF_APP) is positive and significant in Models 2 and $9(p<0.01)$ providing support for the hypothesis and suggesting that MNE subsidiaries located in Turkey implement competencebased performance appraisal systems more extensively than domestic Turkish firms. There is also support for H1b. The coefficient of performance-based compensation (PERF_COMP) is positive and significant in Models $3(p<0.01)$ and $9(p<0.05)$, suggesting that there exists a significant variation between MNE subsidiaries and domestic Turkish firms with regard to the implementation level of performance-based compensation.

There is no support for H1c. The coefficient of internal communication (INT_COMM) is not significant in Models 4 and 9, suggesting that MNE subsidiaries do not differ from domestic Turkish firms with respect to the level of internal communication. There is a strong support for H1d. The positive and significant coefficients for employee empowerment (EMPOWER) in Models 5 and $9(p<0.01)$ confirm the view that MNE subsidiaries located in Turkey rely more heavily on employee empowerment than domestic Turkish firms. The positive and significant coefficients on HRM department status (HRMD_STATUS) in Models $6(p<0.01)$ and $9(p<0.05)$ show that MNE subsidiaries operating in Turkey place more emphasis on the strategic role of human resources department than domestic Turkish firms.

As hypothesized by H2a, the coefficient of employee training (TRAINING) is not significant in Models 7 and 9, indicating that there is no significant variation between MNE subsidiaries and domestic Turkish firms with respect to the implementation level of employee training. 
Similarly, we fail to reject $\mathrm{H} 2 \mathrm{~b}$ in that the coefficient of merit-based promotion (MERIT_PRO) is not significant in both Models 8 and 9, indicating that there is no significant variation between both groups of firms in terms of the implementation level of merit-based promotion systems.

Table 4 shows that there is no support for H3a in that the level of emphasis on each of the seven HRM practices by MNE subsidiaries located in Turkey does not vary with the broad country of origin of MNEs.

\section{[Insert Table 4 over here]}

The level of emphasis on HRM practices by the organizational mode of MNE subsidiaries is shown in Table 5. As discussed earlier, the overall sample of MNE subsidiaries were classified into two groups (WOS or JV) with regard to the organizational mode. Table 5 shows there is only weak support for H3b. Only one HRM practice, internal communication, has a mean score of level of emphasis that is higher and significantly different $(p<0.01)$ for WOSs compared to JVs. It is however clear that the extent of emphasis on the majority of the HRM practices hardly varies with the organizational mode of MNE subsidiary.

\section{[Insert Table 5 over here]}

Table 6 shows that there is moderate support for H3c. Three of the seven HRM practices, competence-based performance appraisal $(p<0.05)$, performance-based compensation $(p<0.1)$ and employee empowerment $(p<0.1)$, indicate significant differences in the mean scores of emphasis with respect to the establishment mode of MNE subsidiary (greenfield or acquisition). As it is readily apparent from Table 6 that the level of emphasis placed on the first two HRM practices by MNE subsidiaries are found to be significantly higher for greenfield mode compared with acquisition mode, while the level of emphasis placed on employee empowerment is significantly higher for acquisition mode than for greenfield mode. 


\section{[Insert Table 6 over here]}

\section{Discussion}

Our analysis confirmed support for H1a, reinforcing the expectation that the specific 'sociocultural contingencies' (Pudelko and Harzing 2007) at play in the Turkish context impact significantly on HRM practices. Specifically, the historical lack of objectivity in performance appraisals in the Turkish context, owing to a lack of scientific underpinning of measures of performance (Aycan 2001), appears to have limited the uptake of competence-based appraisal. Similarly, the fact that Turkey is below the world average on performance orientation (Kabasakal and Bodur 1998) arguably limits the uptake of such systems amongst domestic firms.

The support for H1b confirms that there is significant variation between MNE subsidiaries and domestic Turkish firms with regard to the level of implementation of performance-based compensation. The finding that MNE subsidiaries implement more extensive performance-based compensation compared to Turkish firms resonates with the aforementioned finding with regard to competence-based performance appraisal. Similarly, the collectivist cultural trait evident in the Turkish population is arguably at odds with an individually oriented performance based compensation system.

The strong support for H1d confirms the view that MNE subsidiaries located in Turkey rely more heavily on employee empowerment than domestic Turkish firms. In contrast to communication which can be relatively non-threatening for managers and employees alike, empowerment can involve some fundamental restructuring of operational norms in the workplace and patterns of behaviour. In a culture where paternalism (Aycan and Kanungo 1998), hierarchy (Aycan et al. 2000) and uncertainty avoidance (Kabasakal and Bodur 1998) are dominant characteristics, this finding becomes wholly understandable. Employees and managers alike may feel threatened by the changes in workplace relations which could be associated with empowerment.

Similarly our data confirm that MNE subsidiaries in Turkey place more emphasis on the strategic role of human resources department than domestic Turkish firms. This suggests that 
despite the relative lack of status of HRM in the local context, MNEs continue to place a strong emphasis on the HRM function. It also suggests that, despite some evidence of convergence with regard to specific aspects of HRM practice, ultimately HRM continues to be viewed as a secondary management function in Turkey.

Our hypothesis around internal communication is not supported suggesting that MNE subsidiaries do not differ from domestic Turkish firms with respect to the level of internal communication. This finding may not be surprising as communication is a fairly nebulous construct that can involve fairly limited information sharing between different stakeholders. Hence it does not represent a threat to engrained cultural norms.

Turning to our second set of hypotheses where we expect similarity between MNE subsidiaries and domestic Turkish firms, as hypothesized by H2a, we found no significant variation between MNE subsidiaries and domestic Turkish firms with respect to the implementation level of employee training. This finding suggests that Turkish firms have reacted positively to the challenges of up-skilling the workforce and have invested significantly in training and development in recent years. This finding may be a reaction to the heightened expectations of the emerging cohort of young educated employees who have entered the workforce in recent years.

Similarly, there was no evidence of significant variation between both groups of firms in terms of the implementation of merit-based promotion systems. This finding is in line with our expectations and suggests that merit based promotion systems do play a role in the Turkish HRM system. However, one would have to be cautious in interpreting this finding owing to the fact that the uptake of competence-based performance appraisal is low, as is performance based compensation. Therefore, how merit is established in Turkish firms appears to warrant further investigation.

The fact that the level of emphasis on each of the seven HRM practices by MNE subsidiaries located in Turkey does not vary with the broad country of origin of MNEs suggests that the implementation level of HRM practices is independent of the nationality of the MNE subsidiaries in the Turkish context. Similarly, it is clear that the extent of emphasis on the majority of the HRM practices hardly varies with the organizational mode of the MNE 
subsidiary. These findings provide a degree of support for Pudelko and Harzing's (2007) conclusion that convergence on a best practice model is present, at least with regard to the MNE subsidiaries in our sample. It also resonates with Brewster et al.'s (2007) assertion that firms which operate across national boundaries are particularly exposed to the forces of globalization and hence are most likely to acquiesce to dominant management practices aimed at enhancing competitiveness, such as HRM.

However, it is readily apparent from Table 6 that the level of emphasis placed on the first two HRM practices by MNE subsidiaries are found to be significantly higher for a greenfield mode compared with an acquisition mode, while the level of emphasis placed on employee empowerment is significantly higher for acquisition mode than for greenfield mode. These findings appear to reinforce the idea that certain cultural traits in the Turkish context are so strong and at odds with Western notions of HRM that they significantly restrict the implementation of these practices. Tellingly, two of the three variables which emerge as significantly different in greenfield sites versus acquisitions-competence-based performance appraisal and performance-based compensation-are the same as the ones which diverge between MNEs and local firms. This suggests that the practices are so at odds with Turkish cultural traditions that it is very difficult to change them once they are in place. However, employee empowerment, which also diverged between local firms and MNEs is clearly seen as a means through which management can gain employee commitment in the context of acquisitions. It is apparent that the notion of employees being involved in management decision-making and the shifting of the boundaries with regard to hierarchies and power relationships may not sit well with Turkish employees. This may suggest that although the practice is used to a significant degree in the context of acquisitions, the extent to which employees actually engage with the process may be open to question.

\section{Conclusion and Implications}

This study supports the idea that MNEs do not adapt HRM practices that are easy to diffuse, control and manage and reflect a core organizational value to the local context. Specifically, we found significant differences between MNE subsidiaries located in Turkey and domestic 
Turkish firms in relation to competence-based performance appraisal, performance-based compensation, employee empowerment and the strategic emphasis placed on the HRM department. These findings reinforce the importance of the cultural institutional context in influencing the nature of HRM policies in local firms, with Turkish firms deploying significantly different HRM practices to MNE subsidiaries. Specifically, we point to the lack of scientific underpinning of measures of performance (Aycan 2001), which appears to have limited the uptake of competence-based appraisal. Similarly, the fact that Turkey is below the world average on performance orientation (Kabasakal and Bodur 1998) and the collectivist cultural trait evident in the Turkish population (Aycan and Kanungo 1998) arguably limit the uptake of such systems amongst domestic firms. In a culture where paternalism, hierarchy (Aycan et al. 2000) and uncertainty avoidance (Kabasakal and Bodur 1998) are dominant characteristics, this finding becomes wholly understandable. Our findings also suggest that, despite some evidence of convergence with regard to specific aspects of HRM practices, ultimately HRM continues to be viewed as a secondary management function in Turkey.

Further, in line with Pudelko and Harzing's (2007) recent findings, we argue that there is evidence of the emergence of an established set of best practice HRM practices in the MNEs sector, reflected in the fact that HRM in the MNE subsidiaries did not vary greatly based on their country of origin. This also resonates with Brewster et al.'s (2007) conclusion that MNEs appear to do things differently to other firms within the same national context. A degree of this convergence could be attributed to rational adaptation of HRM practices designed to maximize the contribution of employees to the organization. Concomitantly however it is likely that there is a degree of mimetic isomorphism driving the convergence of HRM practices in these MNEs. The symbolic character of specific practices, such as for example performance-based compensation, signals that these MNEs belong to a particular social context (Fernandez-Alles et al. 2006). Regardless, the finding that MNEs display similar HRM practices regardless of nationality does provide a degree of support for the convergence thesis. It also supports our assertion that HRM practices that are easy to diffuse, control and manage and reflect a core organizational value will not be adapted to the local context. 
We also identify some instances where MNEs are more likely to adapt their HRM practices to the local context. We posit that this is more likely with regard to HRM practices that are difficult to diffuse, control and manage and require sensitivity to local institutional pressures. This is evident with regard to employee training, merit-based promotion and internal communication.

Theoretically our findings point to the key factors which determine whether MNEs alter their HRM practices to local contexts: the relative ease of diffusing and managing a standard but internally-valued practice across borders (Björkman and Lervik 2007), and the strength of local cultural and institutional imperatives (Gunnigle et al. 2002). Specifically, those HRM practices utilized by MNEs as critical mechanisms for coordinating and controlling the activities of their subsidiaries and are less likely to be altered to fit the local context because of their importance to the organization. However, other HRM practices may be altered based on local cultural and institutional imperatives (Björkman and Lervik 2007). For example, for subsidiaries of MNEs entering a new market, the need to establish legitimacy and adapt to institutionally accepted practice creates an external driver that might overrule internal pressures.

On balance our findings support the idea that there is a degree of convergence in HRM practices among MNEs acting globally, regardless of their national origin. However in line with Brewster et al.'s (2007) recent findings, there is equally little evidence of MNEs pioneering a set of global best practices which are being disseminated into host countries. The nature of HRM practices in indigenous firms looks quite different to their MNE counterparts. Thus it appears that isomorphic pressures in the home country of the MNE, the host country of subsidiaries or indeed of the MNE community in a specific host country are in themselves not strong enough to force complete convergence in any particular context. There are a range of forces at play and HRM practice in any given firm is a reflection of the comparative strength of competing rules, norms and conventions (see Brewster et al. 2007). In line with some emerging contributions (Wood et al. 2009), our findings provide some evidence of the co-existence of a (limited) number of alternative paradigms of management within a specific national context. 
The study clearly has implications for the HRM profession in Turkey. Our findings reinforce earlier findings (see Aycan 2001 for a review) that Turkish firms have yet to embrace HRM practices to the degree that they are applied in other contexts. The reasons for this have been articulated elsewhere (Aycan 2001) and include negative attitudes toward utilizing scientifically-based knowledge in Turkish firms, and limited specialization and certification of the HRM profession in Turkey meaning that the majority of HRM professionals have limited if any specialized training in the area. Thus, from a public policy perspective, further investment in the development of the HRM profession through education and certification seems apposite and timely. A key strand of this should be the consideration of the extent to which western human resource practices are appropriate in the Turkish context and the extent to which they require adaptation. The resource requirements of implementing global best practices should also be emphasized, and should inform practice. For managers of MNEs establishing in the Turkish context, our findings suggest that those HRM practices which are central to the MNE's strategic control and coordination objectives can be successfully implemented in the Turkish context. However, not all HRM practices can be successfully transferred and some such training and development and internal career development which are more difficult to diffuse, control and manage often must be adapted to account for the local context.

Our data do have a number of limitations. While the quantitative nature of the study does provide us with a broad overview of trends with regard to convergence/divergence of HRM practices in the Turkish context, it does not allow us to investigate how such HRM practices are in fact implemented. Are HQ mandated practices which are at odds with Turkish traditions actually internalized by subsidiary actors or merely implemented at the surface level or ceremonially adopted (e.g., Kostova 1999; Björkman and Lervik 2007)? Further research in a qualitative tradition could be used to explore these issues in more complete terms. Furthermore, given the low level of uptake of competence-based performance appraisal and performance-based compensation, how merit is established in Turkish firms warrants further investigation. There also appears to be scope to further explore employee perceptions of high performance HRM systems. 
All in all our findings shed further light on the convergence versus divergence debate. Specifically, we hope to have provided novel insights into why certain HRM practices converge while others do not and in an interrelated way, why and which HRM practices are adapted to the new context by both the MNE and domestic firms. In relation to the former the relative ease of diffusing and managing a standard but internally-valued practice across borders combined with the strength of local cultural and institutional imperatives are particularly significant. Specifically, HRM practices utilized as central mechanisms of coordination and control are less likely to be altered to fit the local context because of their importance to the organization. However, other HRM practices may be altered based on local cultural and institutional imperatives where they are less central to the MNEs control and coordination objectives. Indeed, the malleability of HRM practices emerges as central in determining which practices are adapted and which are not. 


\section{References}

Almond, P. (2011). Revisiting 'country-of-origin' effects in multinational corporations. Human Resource Management Journal, 21(3), 258-271.

Amemiya, T. (1981). Qualitative response models: A survey. Journal of Economic Literature, 19: $1483-1536$.

Aycan, Z. (2001). Human resource management in Turkey: Current issues and future challenges. International Journal of Manpower, 22: 252-60.

Aycan, Z. and Fikret-Pasa, S. (2000). Leadership preferences, career choices and work motivation in Turkey: A national profile and regional differences. Paper presented at $15^{\text {th }}$ International Congress of the International Association of Cross-Cultural Psychology, USA.

Aycan, Z. and Kanungo, R.N. (1998). Paternalism: Towards conceptual refinement and operationalization. Paper presented at the 14th International Congress of CrossCultural Psychology, USA, August.

Aycan, Z., Kanungo, R.N., Mendonca, M., Yu, K., Deller, J., Stahl, G., and Khyrsid, A. (2000). Impact of culture on human resource management practices: A 10 country comparison. Applied Psychology: An International Review, 49: 192-220.

Barney, J.B. (1991). Firm resources and sustained competitive advantage. Journal of Management. 17: 99-120.

Bartlett, C.A. and Ghoshal, S. (1989). Managing Across Borders: The Transnational Solution. Boston, Mass.: Harvard Business School Press.

Beaumont, P.B., Cressey, P., and Jakobsen, P. (1990). Key industrial relations: West German subsidiaries in Britain. Employee Relations. 12(6): 3-7.

Björkman, I. and Lervik, J.E. (2007). Transferring HRM practices within multinational enterprises. Human Resource Management Journal, 17: 320-335.

Björkman, I., Fey, C.F., and Park, H.J. (2007). Institutional theory and MNC subsidiary HRM practices: Evidence from a three country study. Journal of International Business Studies, 38: 430-45.

Boxall, P. and Macky, K. (2009). Research and theory on high-performance work systems: Progressing the high-involvement stream. Human Resource Management Journal, 19(1): 3-23.

Budhwar, S. and Mellahi, K. (2007). Introduction: human resource management in the Middle East. International Journal of Human Resource Management, 18: 2-10.

Brewster, C. (2007). Comparative HRM: European views and perspectives. International Journal of Human Resource Management, 18: 769-787.

Brewster, C., Wood, G., and Brookes, M. (2007). Similarity, isomorphism or duality: Recent survey evidence on the human resource management policies of multinational corporations. British Journal of Management, 19: 320-342.

Chang, Y.Y., Mellahi, K. and Wilkinson, A. (2009). Methods of control and emerging MNCs in the UK. International Journal of Human Resource Management. 26(1): 76-91.

Collings, D. and Mellahi, K. (2009). Strategic Talent Management: A review and research agenda. Human Resource Management Review, 19: 304-313.

Collings, D., Demirbag, M., Mellahi, K., and Tatoglu, E. (2010). Strategic orientation, human resource management practices and organizational outcomes: Evidence from Turkey. International Journal of Human Resource Management, 21: 2589-2631.

Cooke, F.L., Wood, G., Psychogios, A.G., and Szamosi, L.T. (2011). HRM in emergent market economies: Evidence and implications from Europe. Human Resource Management Journal. doi: 10.1111/j.1748-8583.2011.00181.x 
Deephouse, D. (1996). Does isomorphism legitimate? Academy of Management Journal. 39(4): 1024-1039.

Delery, J.E. and Doty, D.H. (1996). Modes of theorizing in strategic human resource management: Tests of universalistic, contingency, and configurational performance predictions. Academy of Management Journal, 39: 802-835.

Demirbag, M., Glaister, K.W., and Tatoglu, E. (2007). Institutional and transaction cost influences on MNEs' ownership strategies of their affiliates: Evidence from an emerging market. Journal of World Business, 42(4): 418-434.

DiMaggio, P.J. and Powell, W.W. (1983). The iron cage revisited: Institutionalism and collective rationality in organizational fields. American Sociological Review, 48: 147160.

Emery, F. (1980). Designing socio-technical systems for greenfield sites. Journal of Occupational Behavior, 1(1): 19-27.

Fernandez-Alles, M., Cuevas-Rodriguez, G., and Valle-Cabrera, R. (2006). How symbolic remuneration contributes to the legitimacy of the company: An institutional explanation. Human Relations, 59: 961-992.

Ferner, A. (1997). Country of origin effects and HRM in multinational companies. Human Resource Management Journal, 7(1): 19-37.

Ferner, A., Quintanilla, J. and Varul, M.Z. (2001). Country-of-origin effects, host-country effects, and the management of HR in multinationals: German companies in Britain and Spain. Journal of World Business, 36(2): 107-127.

Fey, C.F. and Bjorkman, I. (2001). The effect of human resource management practices on MNC subsidiary performance in Russia. Journal of International Business Studies, 32(1): 59-75.

Fey, C.F., Bjorkman, I., and Pavlovskaya, A. (2000). The effect of human resource management practice on firm performance in Russia. International Journal of Human Resource Management, 11: 1-18.

Fikret-Pasa, S., Kabasakal, H., and Bodur, M. (2001). Society, organizations, and leadership in Turkey. Applied Psychology: An International Review, 50: 559-589.

GDFI (2008). Foreign Investment Report, July 2008. Ankara.

Geary, J. and Roche, W.K. (2001). Multinationals and human resource practices in Ireland: A rejection of the 'New Conformance Thesis'. International Journal of Human Resource Management, 12: 109-127.

Geringer, J.M. and Frayne, C.A. (1990). Human resource management and international joint venture control: A parent country perspective. Management International Review, 30 (special issue), 103-120.

Geppert, M., Matten, D., and Williams, K. (2003). Change management in MNCs: How global convergence intertwines with national diversity. Human Relations, 56: 807-838.

Glaister, K.W., Dincer, O., Tatoglu, E., Demirbag, M., and Zaim, S. (2008). A causal analysis of formal strategic planning and firm performance. Management Decision, 46(3): 365391.

Gooderham, P.N., Nordhaug, O. and Ringdal, K. (1999). Institutional and rational determinants of organizational practices: Human resource management in European firms. Administrative Science Quarterly, 44: 507-531.

Guest, D.E. (1990). Human resource management and the American dream. Journal of Management Studies, 27: 977-987.

Guest, D.E. (1997). Human resource management and performance: A review and research agenda. International Journal of Human Resource Management, 12: 263-76. 
Guest, D.E. (2011) Human resource management and performance: Still searching for some answers. Human Resource Management Journal, 21: 3-13.

Gunnigle, P. (1995). Collectivism and the management of industrial relations in greenfield sites. Human Resource Management Journal, 5(3): 24-40.

Gunnigle, P. (1998). Human resource management and the personnel function. In Roche, W.K., Monks, K., and Walsh, J. (Eds.), Human Resource Management Strategies: Policy and Practice in Ireland, Dublin: Oak Tree Press.

Gunnnigle, P., Murphy, K.M., Cleveland, J., Heraty, N., and Morley, M. (2002). Localization in human resource management: Comparing American and European multinational corporations. Advances in International Management, 14: 259-284.

Guthrie, J.P. (2001). High-involvement work practices, turnover and productivity: Evidence from New Zealand. Academy of Management Journal, 44: 180-190.

Hair, J.F., Anderson, R.E., Tatham, R.L., and Black, W.C. (1995). Multivariate Data Analysis. 4th Edition. Englewood Cliffs, New Jersey: Prentice Hall.

Hamill, J. (1984). Multinational corporations and industrial relations in the UK. Employee Relations, 6(5): 12-16.

Hayton, J.C. (2005). Promoting corporate entrepreneurship through human resource management practices: A review of empirical research. Human Resource Management Review, 15: 21-41.

Hiltrop, J.M. (1999). The use of HRM practices in international and domestic organizations. New Zealand Journal of Industrial Relations, 24(1): 47-61.

Hofstede, G. (1980). Culture 's Consequences. Thousand Oaks, CA, Sage.

Hosking, D. and Anderson, N. (1992). Organizational Change and Innovation: Psychological Perspectives and Practices in Europe. London: Routledge.

Huang, T. (2000). Human resource management practices at subsidiaries of multinational corporations and local firms in Taiwan. International Journal of Selection and Assessment, 8: 22-33.

Huselid, M.A. (1995). The impact of human resource management practices on turnover, productivity, and corporate financial performance. Academy of Management Journal, 38: 635-672.

Huselid, M.A., Jackson, S.E., and Schuler, R.S. (1997). Technical and strategic human resource management effectiveness as determinants of firm performance. Academy of Management Journal, 40: 171-188.

Jansen, J.J.P., van den Bosch, F.A.J., and Volberda, H.W. (2006). Explorative innovation, exploitative innovation, and performance: Effects of organizational antecedents and environmental moderators. Management Science, 52(11): 1661-1674.

Kabasakal, H. and Bodur, M. (1998). Leadership, values and institutions: The case of Turkey. Paper presented at Western Academy of Management Conference, Istanbul, June.

Kang, S.-C. and Snell, S.A. (2009). Intellectual capital architectures and ambidextrous Learning: A framework for human resource management. Journal of Management Studies, 46(1): 65-92.

Kaya, N. (2006). The impact of human resource management practices and corporate entrepreneurship on firm performance: Evidence from Turkish firms. International Journal of Human Resource Management, 17: 2074-2090.

Kidger, P.J. (1991). The emergence of international human resource management. International Journal of Human Resource Management, 2: 149-163.

Kostova, T and Roth, K. (2002). Adoption of an organizational practice by subsidiaries of multinational corporations: Institutional and relational effects. Academy of Management Journal, 45: 215-233. 
Kostova, T. (1999). Transnational transfer of strategic organizational practices: A contextual perspective. Academy of Management Review, 24: 308-324.

Kuvaas, B. and Dysvik, A. (2010). Exploring alternative relationships between perceived investment in employee development, perceived supervisor support and employee outcomes. Human Resource Management Journal, 20(2): 138-156.

Lazear, E. (2000). Performance, pay and productivity. American Economic Review, 90: 13461361.

Lu, Y. and Bjorkman, I. (1997). HRM in China-Western Joint Ventures: MNC standardization versus localization. International Journal of Human Resource Management, 8(5): 614-628.

MacDuffie, J.P. (1995). Human resource bundles and manufacturing performance: Organizational logic and flexible production systems in the world auto industry. Industrial and Labor Relations Review, 48: 197-221.

McGraw, P. (2002). The HR function in local and overseas firms: Evidence from the PriceWaterhouseCoopers-Cranfield HR project. Asia Pacific Journal of Human Resource, 40(2): 205-227.

Mellahi, K. and Collings W. (2010). The barriers to effective global talent management: The example of corporate elites in MNEs. Journal of World Business, 45: 143-149.

Mellahi, K., Demirbag, M., and Riddle, L. (2010). Multinationals in the Middle East: challenges and opportunities. Journal of World Business, 46(4): 406-410.

Minbaeva, D., Pedersen, T., Bjorkman, I., Fey, C.F., and Park, H.J. (2003). MNC knowledge transfer, subsidiary absorptive capacity, and HRM. Journal of International Business Studies, 34: 586-599.

Ozcelik, A.O. and Aydinli, F. (2006). Strategic role of HRM in Turkey: A three-country comparative analysis. Journal of European Industrial Training, 30(4): 310-27.

Ozcelik, G. and Ferman, M. (2006). Competency approach to human resource management: Outcomes and contributions in a Turkish cultural context. Human Resource Development Review, 5: 72-91.

Park, R., Appelbaum, E., and Kruse, D. (2010). Employee involvement and group incentives in manufacturing companies: a multi-level analysis. Human Resource Management Journal, 20(3): 227-243.

Park, S.H. and Ungson, G.R. (1997). The effect of national culture, organizational complementarity and economic motivation on joint venture dissolution. Academy of Management Journal, 40(2): 279-307.

Pfeffer, J. (1998). The Human Equation: Building Profits by Putting People First. Boston, Harvard Business School Press.

Pudelko, M. and Harzing, A.W. (2007). Country-of-origin, localization or dominance effect? An empirical investigation of HRM practices in foreign subsidiaries. Human Resource Management, 46: 535-559.

Purcell, J., Marginson, P., Edwards, P. and Sisson, K. (1987). The industrial relations practices of multi-plant foreign owned firms. Industrial Relations Journal, 18(2): 130137.

Rodwell, J. and Teo, S. (1999). The value of employment relations in multinationals: Finding the right balance. International Business Review, 8 (3): 309-321.

Ronen, S. (1986). Equity perception in multiple comparisons: A field study. Human Relations, 39(4): 333-345.

Rosenzweig, P.M. (2006). The dual logics behind international human resource management: pressures for global integration and local responsiveness. In G.K. Stahl and I. Bjorkman (eds) Handbook of Research in International Human Resource Management. Cheltenham, Edward Elgar. 
Rosenzweig, P.M. and Nohria, N. (1994). Influences on human resource management practices in multinational corporations. Journal of International Business Studies, 25: 229-242.

Sahadev, S. and Demirbag, M. (2011). Exploring variations in employment practices in the emerging economies of Europe: assessing the impact of foreign ownership and European integration. Human Resource Management Journal, doi: 10.1111/j.17488583.2011.00183.x

Scott-Lennon, F. (1995). The Appraisals Pocketbook. Alresford, Management Pocketbooks Limited.

Shenkar, O. and Zeira, Y. (1987). Human resource management in international joint ventures. Academy of Management Review, 12(3): 546-57.

Sparrow, P., Schuler, R.S. and Jackson, S.E. (1994). Convergence or divergence: Human resource practices and policies for competitive advantage worldwide. The International Journal of Human Resource Management, 5(2): 267-299.

St-Onge, S., Magnan, M., Thorne, L., and Raymond, S. (2001). The effectiveness of stock option plans: A field investigation of senior executives. Journal of Management Inquiry, 10: 250-266.

Strauss, G. and Hanson, M. (1997). Review article: American anti-management theories of organization: A critique of paradigm proliferation. Human Relations, 50: 1426-1429.

Suchman, M.C. (1995). Managing legitimacy: Strategic and institutional approaches. Academy of Management Review, 20: 571-610.

Tanova, C. and Nadiri, H. (2005). Recruitment and training policies and practices: The case of Turkey as an EU candidate. Journal of European Industrial Training, 29: 694-711.

Teagarden, M.B. and Von Glinow, M.A. (1997). Human resource management in crosscultural contexts: Emic and etic considerations. Management International Review, 37(1): 7-22.

Thompson, P. (2011). The trouble with HRM. Human Resource Management Journal, 21(4), doi. 10.1111/j.1748-8583.2011.00180.x.

Tregaskis, O., Herath, N., and Morley, M. (2001). HRD in multinationals: The global/local mix. Human Resource Management Journal, 11: 34-56.

Tregaskis, O. and Brewster C. (2006). Converging or diverging? A comparative analysis of trends in contingent employment practice in Europe over a decade. Journal of International Business Studies, 37: 111-126.

Turner, T., D’Art, D., and Gunnigle, P. (2001). Multinationals and human resource practices in Ireland: a rejection of the 'new conformance thesis: A reply. International Journal of Human Resource Management, 12: 128-133.

Whitaker, A. (1986). Managerial strategy and industrial relations: A case study of plant relocation. Journal of Management Studies, 23(6): 657-678.

Wood, G., Croucher, R., Brewster, C., Collings, D.G. and Brooks, M. (2009). Varieties of firm: Complementarity and bounded diversity. Journal of Economic Issues, 43(1): 241260.

Wright, P.M. and Boswell, W.R. (2002). Desegregating HRM: A review and synthesis of micro and macro human resource management research. Journal of Management, 28(3): 247-276. 
Figure 1. Conceptual framework

Subsidiary characteristics

- Country of origin

- Organizational mode

- Establishment mode

\section{HRM practices}

- Competence based performance appraisal

- Performance based compensation

- Internal communication

- Employee empowerment

- HRM department status

- Employee training

MNE

subsidiaries

Local firms
Control variables

- Age

- Size

- Industry

- Merit based promotion 
Table 1. Characteristics of questionnaire respondent firms

\begin{tabular}{|c|c|c|c|c|c|}
\hline \multirow[t]{2}{*}{ Characteristic } & & \multicolumn{2}{|c|}{ Turkish firms } & \multicolumn{2}{|c|}{ MNE subsidiaries } \\
\hline & & Number & $\%$ & Number & $\%$ \\
\hline \multirow{4}{*}{$\begin{array}{l}\text { Respondent } \\
\text { type }\end{array}$} & CEO (e.g. general manager, chairman) & 144 & 42.4 & 34 & 22.9 \\
\hline & Deputy general manager & 75 & 22.1 & 13 & 8.8 \\
\hline & HRM managers & 84 & 24.6 & 76 & 51.4 \\
\hline & Planning and other senior managers & 37 & 10.9 & 25 & 16.9 \\
\hline \multirow{10}{*}{$\begin{array}{l}\text { Industry } \\
\text { sector }\end{array}$} & Industrial, automotive and electrical equip. & 37 & 10.9 & 8 & 5.4 \\
\hline & Food, textile and paper & 72 & 21.2 & 9 & 6.1 \\
\hline & Metal, wood, leather and glass & 28 & 8.2 & 6 & 4.1 \\
\hline & Chemical and pharmaceuticals & 11 & 3.2 & 13 & 8.8 \\
\hline & Other manufacturing & 30 & 8.8 & 13 & 8.8 \\
\hline & Wholesale and retail trade & 49 & 14.4 & 18 & 12.2 \\
\hline & Computer and engineering services & 16 & 4.7 & 9 & 6.1 \\
\hline & Financial services and consultancy & 31 & 9.1 & 22 & 14.9 \\
\hline & Hospitality and leisure services & 23 & 6.9 & 24 & 16.2 \\
\hline & Other services & 43 & 12.6 & 26 & 17.6 \\
\hline \multirow[t]{3}{*}{ Size } & Small size & 86 & 25.3 & 23 & 15.5 \\
\hline & Medium size & 149 & 43.8 & 46 & 31.1 \\
\hline & Large size & 105 & 30.9 & 79 & 53.4 \\
\hline $\begin{array}{l}\text { Years of } \\
\text { operation }\end{array}$ & Mean & \multicolumn{2}{|c|}{23.97} & \multicolumn{2}{|c|}{19.22} \\
\hline & $N$ & \multicolumn{2}{|c|}{340} & \multicolumn{2}{|c|}{148} \\
\hline
\end{tabular}


Table 2. Descriptive statistics and correlation coefficients of variables

\begin{tabular}{|c|c|c|c|c|c|c|c|c|c|c|c|c|c|c|c|c|c|c|c|c|c|}
\hline Variable name & Definition & Mean & S.D. & 1 & 2 & 3 & 4 & 5 & 6 & 7 & 8 & 9 & 10 & 11 & 12 & 13 & 14 & 15 & 16 & 17 & 18 \\
\hline 1. PERF_APP & Competence-based performance appraisal & 0.67 & 0.26 & 1.00 & & & & & & & & & & & & & & & & & \\
\hline 2. PERF_COMP & Performance-based compensation & 3.54 & 0.76 & $0.19 *$ & 1.00 & & & & & & & & & & & & & & & & \\
\hline 3. INT_COMM & Internal communication & 3.98 & 0.64 & 0.12 & $0.16^{*}$ & 1.00 & & & & & & & & & & & & & & & \\
\hline 4. EMPOWER & Employee empowerment & 3.69 & 0.68 & $0.15^{*}$ & $0.35 *$ & $0.40^{*}$ & 1.00 & & & & & & & & & & & & & & \\
\hline 5. HRMD_STATUS & HRM department status & 3.69 & 0.86 & $0.31 *$ & $0.28 *$ & $0.31^{*}$ & $0.33 *$ & 1.00 & & & & & & & & & & & & & \\
\hline 6. TRAINING & Employee training & 3.17 & 0.85 & -0.01 & $0.14 *$ & 0.01 & 0.02 & 0.03 & 1.00 & & & & & & & & & & & & \\
\hline 7. MERIT_PRO & Merit-based promotion & 3.96 & 0.63 & 0.25 & $0.26^{*}$ & $0.46^{*}$ & $0.43^{*}$ & $0.24 *$ & 0.04 & 1.00 & & & & & & & & & & & \\
\hline 9. LN_SIZE & Logarithm of firm size & 5.21 & 1.69 & -0.12 & $0.23 *$ & 0.03 & 0.12 & 0.05 & 0.08 & $0.35 *$ & $0.30^{*}$ & 1.00 & & & & & & & & & \\
\hline 10. IND_ELECT & Industrial, automotive and electrical equipment & 0.09 & 0.29 & -0.01 & -0.08 & 0.02 & -0.05 & -0.03 & 0.06 & 0.05 & 0.07 & -0.05 & 1.00 & & & & & & & & \\
\hline 11. FOOD_TEXT & Food, textile and paper & 0.17 & 0.37 & 0.01 & $-0.14 *$ & -0.03 & 0.03 & 0.03 & -0.02 & -0.03 & -0.01 & -0.04 & $-0.14 *$ & 1.00 & & & & & & & \\
\hline 12. METAL_WOOD & Metal, wood, leather and glass & 0.07 & 0.25 & -0.05 & -0.01 & -0.08 & 0.04 & 0.01 & -0.04 & -0.10 & 0.01 & -0.07 & -0.08 & -0.12 & 1.00 & & & & & & \\
\hline 13. CHEM_PHAR & Chemical and pharmaceuticals & 0.05 & 0.21 & -0.05 & 0.08 & 0.04 & -0.08 & 0.03 & 0.04 & 0.04 & 0.08 & 0.01 & -0.07 & -0.10 & -0.06 & 1.00 & & & & & \\
\hline 14. OTH_MANUF & Other manufacturing & 0.09 & 0.28 & -0.07 & -0.03 & 0.01 & 0.02 & 0.08 & 0.06 & -0.07 & -0.04 & -0.03 & -0.10 & $-0.14^{*}$ & -0.08 & -0.07 & 1.00 & & & & \\
\hline 15. TRADE & Wholesale and retail trade & 0.14 & 0.34 & 0.04 & 0.03 & 0.04 & -0.06 & -0.04 & -0.12 & -0.06 & $-0.15^{*}$ & -0.08 & -0.12 & $-0.17^{*}$ & -0.11 & -0.09 & -0.12 & 1.00 & & & \\
\hline 16. COMP_ENG & Computer and engineering services & 0.05 & 0.22 & 0.04 & 0.03 & 0.03 & 0.02 & -0.03 & 0.08 & -0.05 & -0.10 & -0.11 & -0.07 & -0.10 & -0.06 & -0.05 & -0.07 & -0.09 & 1.00 & & \\
\hline 18. HOSP_LEIS & Hospitality and leisure services & 0.10 & 0.29 & 0.04 & 0.03 & -0.11 & -0.02 & -0.01 & -0.02 & 0.05 & -0.06 & -0.03 & -0.10 & $-0.14 *$ & -0.09 & -0.07 & -0.10 & -0.13 & -0.07 & -0.11 & 1.00 \\
\hline
\end{tabular}

${ }^{*} p<0.001$ (two-tailed test)

$\mathrm{N}=488$ 
Table 3. Results of logistic regressions

\begin{tabular}{|c|c|c|c|c|c|c|c|c|c|c|c|}
\hline Hypothesis & Variable name & Definition & Model 1 & Model 2 & Model 3 & Model 4 & Model 5 & Model 6 & Model 7 & Model 8 & Model 9 \\
\hline H1a & PERF_APP & Competence-based performance appraisal & & $2.64 * * *$ & & & & & & & $2.41 * * *$ \\
\hline H1b & PERF_COMP & Performance-based compensation & & & $0.69 * * *$ & & & & & & $0.47 * *$ \\
\hline H1c & INT_COMM & Internal communication & & & & 0.04 & & & & & -0.47 \\
\hline H1d & EMPOWER & Employee empowerment & & & & & $0.48 * * *$ & & & & $0.58 * * *$ \\
\hline H1e & HRMD_STATUS & HRM department status & & & & & & $0.54 * * *$ & & & $0.27 * *$ \\
\hline H2a & TRAINING & Employee training & & & & & & & 0.11 & & 0.08 \\
\hline H2b & MERIT_PRO & Merit-based promotion & & & & & & & & 0.19 & -0.44 \\
\hline \multicolumn{12}{|c|}{ Control variables } \\
\hline & AGE & Firm age & $-0.03 * * *$ & $-0.03 * * *$ & $-0.03 * * *$ & $-0.03 * * *$ & $-0.03 * * *$ & $-0.03 * * *$ & $-0.03 * * *$ & $-0.03 * * *$ & $-0.03 * * *$ \\
\hline & LN_SIZE & Logarithm of firm size & $0.44 * * *$ & $0.38 * * *$ & $0.45 * * *$ & $0.44 * * *$ & $0.43^{* * *}$ & $0.36 * * *$ & $0.42 * * *$ & $0.41 * * *$ & $0.31 * * *$ \\
\hline & IND_ELECT & Industrial, automotive and electrical equip. & -0.80 & -0.67 & -0.79 & -0.64 & -0.85 & -0.78 & -0.82 & -0.83 & -0.78 \\
\hline & FOOD_TEXT & Food, textile and paper & $-1.52 * * *$ & $-1.31 * * *$ & $-1.48 * * *$ & $-1.51 * * *$ & $-1.53 * * *$ & $-1.41 * * *$ & $-1.49 * * *$ & $-1.52 * * *$ & $-1.34 * * *$ \\
\hline & METAL_WOOD & Metal, wood, leather and glass & $-1.02 *$ & $-1.22 *$ & -0.90 & $-1.05 *$ & $-1.02 *$ & -0.89 & $-1.19 *$ & $-1.10^{*}$ & $-1.16^{*}$ \\
\hline & CHEM_PHAR & Chemical and pharmaceuticals & $1.01 *$ & 0.92 & $1.06 * *$ & $0.91 *$ & $0.91 *$ & $1.06 * *$ & 0.67 & $1.02 *$ & 0.33 \\
\hline & OTH_MANUF & Other manufacturing & -0.36 & -0.34 & -0.32 & -0.40 & -0.44 & -0.21 & -0.38 & -0.39 & -0.32 \\
\hline & TRADE & Wholesale and retail trade & -0.63 & -0.55 & -0.62 & -0.62 & -0.57 & -0.53 & -0.58 & -0.61 & -0.43 \\
\hline & COMP_ENG & Computer and engineering services & -0.05 & -0.21 & -0.09 & -0.16 & -0.20 & -0.10 & 0.03 & -0.10 & -0.33 \\
\hline & FIN_CONS & Financial services and consultancy & -0.16 & -0.17 & -0.06 & -0.21 & -0.18 & -0.01 & -0.05 & -0.14 & 0.02 \\
\hline & HOSP_LEIS & Hospitality and leisure services & 0.35 & 0.31 & 0.59 & 0.32 & 0.34 & 0.31 & 0.23 & 0.30 & 0.15 \\
\hline \multicolumn{3}{|l|}{ Intercept } & $-2.17 * * *$ & $-3.74 * * *$ & $-4.77 * * *$ & $-2.28 * *$ & $-3.92 * * *$ & $-3.82 * * *$ & $-2.37 * * *$ & $-2.71 * * *$ & $-4.60 * * *$ \\
\hline & \multicolumn{2}{|l|}{ Model chi-square } & $85.31^{* * *}$ & $111.97 * * *$ & $105.53 * *$ & $79.74 * * *$ & $91.28 * * *$ & $95.35 * * *$ & 69.91*** & $78.19 * * *$ & $102.96 * * *$ \\
\hline & \multicolumn{2}{|l|}{ Sensitivity } & 0.38 & 0.51 & \begin{tabular}{|l|}
0.47 \\
\end{tabular} & \begin{tabular}{|l|}
0.39 \\
\end{tabular} & \begin{tabular}{|l|}
0.39 \\
\end{tabular} & 0.45 & 0.36 & 0.37 & 0.55 \\
\hline & \multicolumn{2}{|l|}{ Specificity } & 0.89 & 0.87 & 0.91 & 0.87 & 0.88 & 0.89 & 0.89 & 0.87 & 0.87 \\
\hline & \multicolumn{2}{|c|}{ Correct ratio } & 0.74 & 0.77 & 0.78 & 0.74 & 0.74 & 0.76 & 0.73 & 0.72 & 0.77 \\
\hline & \multicolumn{2}{|c|}{ Proportional chance criterion } & 0.57 & 0.56 & 0.57 & 0.56 & 0.56 & 0.56 & 0.56 & 0.56 & 0.55 \\
\hline & \multicolumn{2}{|c|}{ Cox \& Snell R square } & 0.18 & 0.23 & 0.21 & 0.17 & 0.19 & 0.20 & 0.16 & 0.17 & 0.25 \\
\hline & \multicolumn{2}{|c|}{ Nagelkerke R square } & 0.25 & 0.32 & 0.30 & 0.24 & 0.26 & 0.28 & 0.23 & 0.24 & 0.35 \\
\hline
\end{tabular}

\section{Notes:}

${ }^{*} p<0.1 ; * * p<0.05 ; * * * p<0.01$ (two-tailed test)

Positive signs indicate the relative use of HRM practices by MNE subsidiaries in Turkey, while negative signs indicate their relative use by domestic Turkish firms. 
Table 4. HRM practices and broad country of origin of MNE subsidiaries

\begin{tabular}{lcccc}
\hline HRM practices & Group & Mean & SD & F-value \\
\hline \multirow{2}{*}{ Competence-based performance appraisal } & USA \& UK & 0.81 & 0.21 & \\
& EUROPE & 0.81 & 0.22 & \\
& ASIA & 0.84 & 0.16 & 0.19 \\
\hline \multirow{2}{*}{ Performance-based compensation } & USA \& UK & 3.82 & 0.69 & \\
& EUROPE & 3.69 & 0.72 & \\
& ASIA & 3.79 & 0.72 & 0.52 \\
\hline \multirow{2}{*}{ Internal communication } & USA \& UK & 4.11 & 0.52 & \\
& EUROPE & 3.97 & 0.67 & \\
& ASIA & 3.85 & 0.83 & 1.42 \\
Employee empowerment & USA \& UK & 3.92 & 0.66 & \\
& EUROPE & 3.85 & 0.69 & \\
& ASIA & 3.58 & 0.40 & 1.75 \\
HRM department status & USA \& UK & 4.06 & 0.86 & \\
& EUROPE & 4.04 & 0.85 & \\
& ASIA & 3.86 & 0.69 & 0.39 \\
\hline \multirow{2}{*}{ Employee training } & USA \& UK & 36.84 & 29.15 & \\
& EUROPE & 35.70 & 51.92 & \\
\hline \multirow{2}{*}{ Merit-based promotion } & ASIA & 34.62 & 26.18 & 0.03 \\
\hline \multirow{2}{*}{$N=148$} & USA \& UK & 4.07 & 0.48 & \\
\hline & EUROPE & 3.96 & 0.57 & \\
\hline & ASIA & 4.16 & 0.41 & 1.31 \\
\hline
\end{tabular}

Table 5. HRM practices and organizational mode of MNE subsidiaries

\begin{tabular}{|c|c|c|c|c|}
\hline HRM practices & Group & Mean & $S D$ & t-value \\
\hline \multirow{2}{*}{ Competence-based performance appraisal } & WOS & 0.82 & 0.21 & \\
\hline & JV & 0.81 & 0.21 & 0.33 \\
\hline \multirow{2}{*}{ Performance-based compensation } & WOS & 3.72 & 0.77 & \\
\hline & JV & 3.82 & 0.59 & -0.87 \\
\hline \multirow{2}{*}{ Internal communication } & WOS & 4.19 & 0.54 & \\
\hline & JV & 3.75 & 0.67 & $4.09 *$ \\
\hline \multirow{2}{*}{ Employee empowerment } & WOS & 3.89 & 0.69 & \\
\hline & JV & 3.79 & 0.59 & 0.87 \\
\hline \multirow{2}{*}{ HRM department status } & WOS & 4.02 & 0.84 & \\
\hline & JV & 4.03 & 0.83 & -0.07 \\
\hline \multirow{2}{*}{ Employee training } & WOS & 33.21 & 33.29 & \\
\hline & JV & 40.07 & 49.09 & -0.92 \\
\hline \multirow{2}{*}{ Merit-based promotion } & WOS & 4.06 & 0.58 & \\
\hline & JV & 3.99 & 0.40 & 0.40 \\
\hline$N=148$ & \multicolumn{4}{|c|}{$W O S=88 ; J V=60$} \\
\hline
\end{tabular}

$* p<0.01$ 
Table 6. HRM practices and establishment mode of MNE subsidiaries

\begin{tabular}{|c|c|c|c|c|}
\hline HRM practices & Group & Mean & $S D$ & t-value \\
\hline \multirow{2}{*}{ Competence-based performance appraisal } & GREENFIELD & 0.83 & 0.19 & \\
\hline & ACQUISITION & 0.74 & 0.26 & $1.97 * *$ \\
\hline \multirow{2}{*}{ Performance-based compensation } & GREENFIELD & 3.81 & 0.71 & \\
\hline & ACQUISITION & 3.56 & 0.66 & $1.85 *$ \\
\hline \multirow{2}{*}{ Internal communication } & GREENFIELD & 4.04 & 0.61 & \\
\hline & ACQUISITION & 3.96 & 0.71 & 0.56 \\
\hline \multirow{2}{*}{ Employee empowerment } & GREENFIELD & 3.80 & 0.65 & \\
\hline & ACQUISITION & 4.04 & 0.66 & $-1.88 *$ \\
\hline \multirow{2}{*}{ HRM department status } & GREENFIELD & 4.05 & 0.85 & \\
\hline & ACQUISITION & 3.96 & 0.80 & 0.55 \\
\hline \multirow{2}{*}{ Employee training } & GREENFIELD & 37.48 & 44.13 & \\
\hline & ACQUISITION & 31.25 & 24.96 & 1.01 \\
\hline \multirow{2}{*}{ Merit-based promotion } & GREENFIELD & 4.02 & 0.49 & \\
\hline & ACQUISITION & 4.03 & 0.62 & -0.02 \\
\hline$N=148$ & \multicolumn{4}{|c|}{ Greenfield $=115 ;$ Acquisition $=33$} \\
\hline
\end{tabular}

${ }^{*} p<0.1 ;{ }^{* *} p<0.05$ 